\title{
EFEKTIVITAS PENYELENGGARAAN RANPERDA PADA DPRD KABUPATEN PANGKEP
}

\author{
The Effectiveness of Implementing Ranperda at Regional House of Representatives Pangkep Regency
}

\author{
Abdul Kadir ${ }^{1}$, Andi Rasjid Pananrangi, Syamsul Bahri ${ }^{1}$ \\ ${ }^{1}$ Program Studi Ilmu Administrasi Negara, Program Pascasarjana, Universitas Bosowa \\ Email: kadiremo@gmail.com \\ Diterima: 25 September 2021 \\ Dipublikasikan: 24 Desember 2021
}

\begin{abstract}
ABSTRAK
Penelitian ini bertujuan untuk mengetahui dan menganalisis: 1) Kualitas penyelenggaraan Ranperda pada DPRD Kabupaten Pangkep. 2) implementasi penyelenggaraan Ranperda pada DPRD Kabupaten Pangkep. Metode penelitian ini menggunakan metode kualitatif dengan tipe deskriptif. Penelitian dilakukan pada DPRD Kabupaten Pangkep. Hasil penelitian menunjukan bahwa: 1) Kualitas penyelenggaraan Ranperda pada DPRD Kabupaten Pangkep bahwa dengan adanya tujuan sebagai dasar hukum bagi APBD (Anggaran Pendapatan dan Belanja Daerah), melaksanakan perintah peraturan perundang-undangan yang lebih tinggi, menambah pendapatan pemerintah daerah, dan meningkatkan kesejahteraan masyarakat khususnya masyarakat di Kabupaten Pangkep. Kejelasan strategi yang ditunjukkan dengan langkah-langkah penyelenggaraan Ranperda dalam pengusulan Ranperda, pembuatan naskah akademik melibatkan pihak ketiga yang di dalamnya terdapat orang-orang ahli, uji publik dalam rangka melihat respons masyarakat, pengajuan Ranperda untuk dibahas di DPRD, pengesahan Ranperda menjadi Perda, dan Sosialisasi Perda (Sosper). Penyusunan program dalam penyelenggaraan Ranperda dengan adanya pembahasan Ranperda melalui Bapemperda (Badan Pembentukan Peraturan Daerah), Panitia Khusus (Pansus), dan gabungan dari beberapa komisi di DPRD Kabupaten Pangkep. Ketersediaan sarana dan prasarana penyelenggaraan Ranperda dalam hal dana anggaran masih kurang maksimal sehingga menjadi faktor yang menghambat dalam penyelenggaraan Ranperda. 2) Implementasi penyelenggaraan Ranperda pada DPRD Kabupaten Pangkep dideskripsikan bahwa komunikasi ditinjau dalam tiga aspek yaitu: (1) transmisi dilakukan dalam bentuk uji publik dan sosialisasi Perda yang bertujuan menginformasikan kepada masyarakat terkait adanya Ranperda yang akan dibahas dan ditetapkan menjadi Perda, (2) pemberian kejelasan juga dilakukan dalam bentuk uji publik dimana melalui uji publik, masyarakat memperoleh informasi yang jelas terkait adanya Ranperda, dan (3) konsistensi ditunjukkan dengan adanya pelaksanaan penyelenggaraan Ranperda berdasarkan perintah UU No. 12 tahun 2011 tentang pengembangan undang-undang dan pedoman.
\end{abstract}

Kata Kunci: Penyelenggaraan Pembahasan Ranperda

\begin{abstract}
This study aims to determine and analyze: 1) The quality of the implementation of the Ranperda at the Pangkep Regency DPRD. 2) implementation of the implementation of the Ranperda at the Pangkep Regency DPRD. This research method uses a qualitative method with a descriptive type. The research was conducted at the Pangkep Regency DPRD. The results of the study show that: 1) The quality of the implementation of the Ranperda at the Pangkep Regency DPRD is that with the aim of being the legal basis for the Regional Budget (Regional Revenue and Expenditure Budget), carrying out higher laws and regulations, increasing local government revenue, and improving people's welfare. especially people in Pangkep Regency. The clarity of the strategy shown by the steps for implementing the Ranperda in proposing the Ranperda, making an academic manuscript involving third parties in which there are experts, public testing in order to see the community's response, submitting the Ranperda to be discussed in the DPRD, ratification of the Ranperda into a Perda, and Socialization of Regional Regulations (Sosper). Preparation of the program in the implementation of the Ranperda with the discussion of the Ranperda through the Bapemperda (Regional Regulation Formation Agency), the Special Committee (Pansus), and a combination of several commissions in the Pangkep Regency DPRD. The availability of facilities and infrastructure for the implementation of the Ranperda in terms of budget funds is still less than optimal so that it becomes a factor that hinders the implementation of the Ranperda. 2) Implementation of the implementation of the Ranperda at the Pangkep Regency DPRD describes that communication is reviewed in three aspects, namely: (1) the transmission is carried out in the form of a public test and dissemination of the Perda which aims to inform the public regarding the existence of a Ranperda that will be discussed and stipulated as a Regional Regulation, (2) granting Clarity is also carried out in the form of a public test where through a public test, the public obtains clear information regarding the existence of a Ranperda, and (3) consistency is shown by the implementation of the implementation of a Ranperda based on the order of Law no. 12 of 2011 concerning the development of laws and guidelines.
\end{abstract}

Keywords: Implementation of the Ranperda Discussion

This work is licensed under Creative Commons Attribution License 4.0 CC-BY International license 


\section{PENDAHULUAN}

Dalam Undang-Undang Republik Indonesia Nomor 23 Tahun 2014 tentang Pemerintahan Daerah disebutkan bahwa Pemerintah Daerah adalah penyelenggaraan urusan pemerintahan oleh Pemerintah Daerah (Yustisia, 2015). Yang dimaksud dengan pemerintah provinsi adalah wakil pimpinan, pejabat, ketua umum yang dilengkapi dengan majelis mekanik teritorial, khususnya asosiasi pemerintah daerah yang terdiri dari sekretaris daerah, tempat kerja, badan khusus daerah dan organisasi yang cakap menjadi kepala daerah. Dewan Perwakilan Rakyat Daerah sebagai komponen penyelenggaraan pemerintahan daerah. DPRD dibentuk untuk melakukan kapasitas fundamental, lebih spesifiknya, unsur-unsur penyusunan pedoman kewilayahan, perencanaan dan pengelolaan. Ketiga kapasitas tersebut dilengkapi dalam struktur penggambaran atau penggambaran. Salah satu unsur vital DPRD untuk membantu pelaksanaan pemerintahan daerah sendiri adalah kapasitas otoritatifnya (Lumolos, 2013).

Dalam perangkat DPRD untuk penyiapan, perencanaan, pembicaraan, proklamasi, pelaksanaan, dan penyebarluasan Peraturan Daerah, juga diatur dalam Undang-Undang Republik Indonesia Nomor 12 Tahun 2011 tentang Pembentukan Peraturan Perundangundangan. Selama masa kewenangannya, terdapat mata kuliah penyusunan Raperda yang saat ini memiliki 2 tahap, khususnya penyusunan Program Pembentukan Peraturan Daerah (Properda) dan Penyusunan Naskah Akademik. Properda (Program Pembentukan Peraturan Daerah) adalah perangkat penyusunan Properda Provinsi atau Peraturan Daerah Kabupaten/Kota yang disusun secara tersusun, terkoordinasi, dan tertib (Indonesia, 2004). Sedangkan karya ilmiah adalah salinan asli dari hasil eksplorasi atau pemeriksaan yang sah dan hasil pemeriksaan lainnya tentang suatu masalah tertentu yang dapat dipertahankan secara deduktif dengan memperhatikan pedoman masalah dalam Rancangan Undang-Undang, Rancangan Peraturan Daerah Provinsi, atau Rancangan Peraturan Daerah Kabupaten/Kota sebagai jawaban untuk masalah tersebut. terlebih lagi, persyaratan yang sah dari masyarakat (Indonesia, 2004).

Pimpinan membuat Prolegda sebagai hasil dari Rencana Pembangunan Jangka Panjang Daerah (RPJPD) dan Rencana Pembangunan Jangka Menengah Daerah (RPJMD) yang diubah menjadi Perda, sedangkan DPRD membuat Prolegda berdasarkan fakta bahwa selain sebagai badan yang berwenang menyetujui untuk membuat Peraturan Daerah, DPRD melalui Peraturan Daerah memutuskan pembenahan arah dan penyelenggaraan pemerintahan di kabupaten, sebagai alasan untuk menyusun strategi publik di daerah, serta mendukung penataan perangkat provinsi dan konstruksi hierarkis perakitan mekanik lokal. Sebagaimana dinyatakan dalam Undang-Undang Republik Indonesia Nomor 12 Tahun 2011 tentang Pembentukan Peraturan Perundang-undangan, maka substansi Peraturan Daerah adalah mengenai pelaksanaan usaha mandiri dan gotong royong daerah, serta mewajibkan keadaan daerah yang luar biasa serta penjabaran tambahan dari ketentuan yang lebih tinggi berlakunya (Indonesia, 2004).

Dari hasil obsevasi peneliti dilapangan dalam penyelenggaraan Ranperda pada DPRD Kabupaten Pangkep bahwa kualitas sumber daya manusia setiap anggota DPRD Kabupaten Pangkep yang membahas Ranperda harus mempunyai hasil atau output yang berdiri sejajar antara kualitas sumber daya manusia anggota DPRD dengan kualitas Perda yang akan di tetapkan. Dalam proses pembahasan Ranperda, keaktifan anggota DPRD dalam setiap tahapan pembahasan Ranperda tentu sangat mempengaruhi kualitas Perda. Keaktifan anggota DPRD ketika naska akademik di terima oleh anggota DPRD, kemudian dilakukan sosialisasi Ranperda kepada masyarakat dan dilanjutkan dalam pembahasan Ranperda di paripurna untuk ditetapkan menjadi Perda. Karena hasil Perda berkualitas atau di butuhkan oleh masyarakat tentu dilihat dari kualitas anggota DPRD.

Menurut Harbani Pasolong, kecukupan pada dasarnya berasal dari kata "dampak" dan istilah ini digunakan sebagai hubungan sebab akibat. Kecukupan dapat dilihat sebagai alasan untuk berbagai faktor. Kecukupan menyiratkan bahwa tujuan yang disusun barubaru ini dapat dicapai atau dengan demikian tujuan tercapai karena interaksi gerakan (Pasolong, 2007).

Eksekusi strategi pada tingkat dasar adalah cara pendekatan untuk mencapai tujuannya, itu saja dan tidak terlalu banyak. Untuk melakukan pendekatan publik, ada dua pilihan langkah yang ada, yaitu langsung melaksanakannya sebagai proyek atau melalui rencana pengaturan bawahan atau anak perusahaan dari strategi tersebut. Pengaturan publik sebagai undang-undang atau pedoman lokal adalah jenis pendekatan yang memerlukan strategi publik ilustratif atau biasa disebut pedoman pelaksanaan.

Mungkin kekuatan utama kabupaten yang mengatur dan mengurus keluarganya sendiri adalah kekuatan untuk menyusun pedoman provinsi (Soejito, 1978). Peraturan Daerah akan menjadi pedoman yang ditetapkan oleh Kepala Daerah dengan persetujuan DPRD dan yang harus memenuhi prasyarat tertentu yang layak dapat memiliki kekuasaan yang sah dan membatasi (Prakoso, 1985). 


\section{METODE}

Jenis Penelitian ini menggunakan jenis penelitian kualitatif dengan tipe deskriptif yang berfokus kepada efektivitas penyelenggaraan Raperda pada DPRD Kabupaten Pangkep.

Prosedur pengumpulan informasi dilakukan dengan menggunakan persepsi, wawancara, tes tulis (Library Exploration), dan pencarian informasi online. Prosedur pemeriksaan informasi dalam penelitian ini dilakukan secara hati-hati dimana informasi tersebut dipilih dengan menggunakan metode penyelidikan informasi ilustratif, khususnya informasi yang telah dikumpulkan banyak baik yang esensial maupun opsional, kemudian pada akhirnya ditarik sebagai jawaban atas permasalahan yang dibahas. Penyusunan informasi dilakukan melalui pengurangan informasi, penyajian informasi dan penarikan akhir serta pengecekan informasi. Sementara itu, keabsahan informasi dalam pemeriksaan ini dilakukan dengan memperluas persepsi, memperluas ketekunan, mencari informasi, membedah kasus negatif, memanfaatkan bahan referensi, dan pemeriksaan bagian terdepan.

\section{HASIL DAN PEMBAHASAN}

\section{Kualitas Penyelenggaraan Ranperda pada Kantor DPRD Kabupaten}

Kualitas penyelenggaraan Ranperda pada kantor DPRD Kabupaten Pangkep ditinjau dalam 8 indikator yaitu (1) Kejelasan tujuan, (2) Kejelasan stategi, (3) Penyusunan program, (4) Tersedianya sarana dan prasarana.

a. Kejelasan Tujuan

Kejelasan tujuan merupakan aspek utama dalam menilai efektivitas penyelenggaraan kegiatan dalam suatu organisasi. Tujuan yang jelas dapat menjadi acuan bagi anggota dalam melaksanakan tugas dan tanggung jawabnya. Demikian halnya dalam penyelenggaraan Ranperda di DPRD Kabupaten Pangkep.

Dari hasil wawancara di atas dapat disimpulkan bahwa penyelenggaraan Ranperda di DPRD Kabupaten Pangkep memiliki kejelasan tujuan yaitu antara lain: (1) sebagai dasar hukum bagi APBD (Anggaran Pendapatan dan Belanja Daerah), (2) melaksanakan perintah peraturan perundang-undangan yang lebih tinggi, (3) menambah pendapatan pemerintah daerah, dan (4) meningkatkan kesejahteraan masyarakat khususnya masyarakat di Kabupaten Pangkep.

b. Kejelasan Strategi

Kejelasan strategi dalam penyelenggaraan Ranperda di DPRD Kabupaten Pangkep merupakan kejelasan mekanisme yang harus dilakukan dalam penyelenggaraan Ranperda sampai pada penetapan menjadi Perda. Mekanisme atau proses awal dari penyenggaraan Ranperda adalah pengusulan Ranperda.

Berdasarkan hasil wawancara yang telah dikemukakan, dapat disimpulkan bahwa terdapat kejelasan strategi dalam penyelenggaraan Ranperda di DPRD Kabupaten Pangkep yang ditunjukkan dengan langkah-langkah yaitu: (1) pengusulan Ranperda, (2) pembuatan naskah akademik melibatkan pihak ketiga yang di dalamnya terdapat orang-orang ahli, (3) uji publik dalam rangka melihat respons masyarakat, (4) pengajuan Ranperda untuk dibahas di DPRD, (5) pengesahan Ranperda menjadi Perda, dan (6) Sosialisasi Perda (Sosper).

\section{c. Penyusunan Program}

Penyusunan program dalam penyelenggaraan Ranperda merupakan proses yang dilakukan setelah perencanaan. Dalam hal ini merupakan proses ketika pengajuan Ranperda ke DPRD Kabupaten Pangkep.

Berdasarkan hasil wawancara di atas, dapat disimpulkan bahwa penyusunan program dalam penyelenggaraan Ranperda di DPRD Kabupaten Pangkep ditunjukkan dengan adanya pembahasan Ranperda melalui Bapemperda (Badan Pembentukan Peraturan Daerah), Panitia Khusus (Pansus), dan gabungan dari beberapa komisi di DPRD Kabupaten Pangkep.

d. Tersedianya Sarana dan Prasarana

Kantor dan yayasan diharapkan dapat membantu metode yang terlibat dalam menjalankan suatu program sehingga berjalan dengan baik. Demikian halnya dengan penyelenggaraan Ranperda di DPRD Kabupaten Pangkep.

Berdasarkan hasil wawancara yang telah dikemukakan, dapat disimpulkan bahwa ketersediaan sarana dan prasarana penyelenggaraan Ranperda di DPRD Kabupaten Pangkep dalam hal dana anggaran masih kurang maksimal sehingga menjadi faktor yang menghambat dalam penyelenggaraan Ranperda.

Implementasi Penyelenggaraan Ranperda pada Kantor DPRD Kabupaten Pangkep

Implementasi penyelenggaraan Ranperda pada kantor DPRD Kabupaten Pangkep ditinjau dalam 4 indikator yaitu: (1) komunikasi, (2) sumber daya, (3) sikap, dan (4) struktur birokrasi.

a. Komunikasi

Komunikasi ditinjau dalam tiga aspek yaitu transmisi, konsistensi, dan kejelasan. Transmisi merupakan penyebaran informasi. Apabila dikaitkan dengan penyelenggaraan Ranperda, implementasi dari transmisi tersebut terlihat dari adanya uji publik dan sosialisasi Perda.

Berdasarkan hasil wawancara di atas, dapat disimpulkan bahwa komunikasi ditinjau dalam tiga aspek yaitu: (1) transmisi dilakukan dalam bentuk uji publik dan sosialisasi Perda yang bertujuan menginformasikan kepada masyarakat terkait adanya Ranperda yang akan dibahas dan ditetapkan menjadi Perda, (2) pemberian kejelasan juga dilakukan dalam bentuk uji publik dimana melalui uji publik, masyarakat memperoleh informasi yang jelas terkait adanya Ranperda, dan (3) konsistensi ditunjukkan dengan adanya pelaksanaan penyelenggaraan Ranperda berdasarkan perintah UU No. 12 tahun 2011 tentang pembentukan peraturan perundang-undangan. 
b. Sumber Daya

Hal utama yang dibutuhkan dalam penyelenggaraan Ranperda adalah Sumber Daya Manusia (SDM) yang memadai. Ranperda yang diajukan kemudian dibahas di DPRD sangat membutuhkan masukan-masukan pemikiran dari SDM yang ahli di bidangnya. Berdasarkan beberapa hasil wawancara yang telah dikemukakan, dapat disimpulkan bahwa sumber daya manusia yang dimiliki DPRD Kabupaten Pangkep dalam penyelenggaraan Ranperda masih kurang memadai sehingga target dari penyelenggaraan Ranperda menjadi tidak tercapai secara maksimal.

c. Sikap

Sikap dalam hal ini merupakan kecenderungan perilaku yang ditunjukkan oleh seluruh pihak yang terlibat dalam penyelenggaraan Ranperda terutama dari pihak DPRD selaku lembaga yang berperan sebagai wadah untuk pembahasan Ranperda menjadi Perda. Berdasarkan beberapa hasil wawancara yang telah dikemukakan, dapat disimpulkan bahwa dalam penyelenggaraan Ranperda, anggota DPRD menunjukkan sikap yaitu: berkoordinasi untuk memecahkan persoalan, bertanggung jawab sebagai lembaga yang memiliki kewenangan dalam membentuk Perda, terbuka dan siap menerima masukan atau kritik dalam penyelenggaraan Ranperda.

d. Struktur Birokrasi

Struktur birokrasi dalam penelitian ini merupakan susunan secara hierarki anggota DPRD yang terlibat dalam penyelenggaraan Ranperda. Berdasarkan beberapa hasil wawancara yang telah dikemukakan, dapat disimpulkan bahwa penyelenggaraan Ranperda di DPRD Kabupaten Pangkep memiliki struktur birokrasi yang memiliki kewenangan khusus terkait penyelenggaraan Ranperda

\section{KESIMPULAN DAN SARAN}

Sumber daya manusia yang dimiliki DPRD Kabupaten Pangkep dalam penyelenggaraan Ranperda masih kurang memadai sehingga target dari penyelenggaraan Ranperda menjadi tidak tercapai secara maksimal. Penyelenggaraan Ranperda di DPRD Kabupaten Pangkep memiliki struktur birokrasi yang memiliki kewenangan khusus terkait penyelenggaraan Ranperda. Dalam penyelenggaraan Ranperda di DPRD Kabupaten Pangkep hendaknya dilakukan pengalokasian anggaran secara efektif karena hal tersebut dapat memberikan dampak krusial terhadap efektifvitas penyelenggaraan Ranperda di DPRD Kabupaten Pangkep.

Perbaikan kualitas Sumber Daya Manusia yang terlibat dalam penyelenggaraan Ranperda khususnya dari pihak DPRD Kabupaten Pangkep perlu dilakukan agar tujuan penyelenggaraan Ranperda dapat dicapai secara maksimal. Masyarakat hendaknya berperan aktif dalam penyelenggaraan Ranperda di DPRD Kabupaten Pangkep karena target utama dari Peraturan Daerah atau Perda yang dihasilkan dalam penyelenggaraan Ranperda adalah masyarakat itu sendiri.

\section{DAFTAR PUSTAKA}

Attamimi, A. H. S. (1992). Teori perundang-undangan indonesia: suatu sisi ilmu pengetahuan perundangundangan Indonesia yang menjelaskan dan menjernihkan pemahaman. UI-Press.

Indonesia, R. (2004b). Undang-Undang Republik Indonesia Nomor 32 Tahun 2004 Tentang Pemerintahan Daerah. Jakarta (ID): RI.

Kurniawan, A. (2005). Transformasi pelayanan publik. Pembaruan.

Lubis, H., \& Huseini, M. (1987). Teori Organisasi: Suatu Pendekatan Makro. Pusat Antar Ilmu-Ilmu Sosial UI: Jakarta.

Lubis, M. S. (1989). Landasan dan Teknik PerundangUndangan. Mandar Maju.

Lumolos, J. (2013). Penguatan Kapasitas DPRD di Era Demokrasi. Bandung: Lepsindo.

Mahmudi, M. (2005). Manajemen Kinerja Sektor Publik. Akademi Manajemen Perusahaan YKPN, Yogyakarta.

Manan, B., Kepresidenan, L., \& Ketiga, C. (2004). Teori dan Politik Konstitusi, Yogyakarta: FH. UII Press, cet. Kedua.

Moleong, Lexy J. 2018. Metode Penelitian Kualitatif. Bandung: PT Remaja Rosdakarya.

Pasolong, H. (2007). Teori administrasi publik. Bandung: Alfabeta.

Perundang-Undangan, P. P. (n.d.). Undang-Undang Republik Indonesia Nomor 12 Tahun 2011 Tentang Perundang-Undangan, T. P. P. (n.d.). Implementasi Undang-undang Nomor 12 Tahun 2011 Tentang Pembentukan Peraturan Perundang-undangan pada Pemerintah Kabupaten Bone.

Prakoso, D. (1985). proses pembuatan peraturan Daerah dan Beberapa Usaha penyempurnaannya. Ghalia Indonesia.

Richard, H. H. (2006). Implementasi Manajemen Stratejik Kebijakan dan Proses, terjemahan Nganam Maksensius. Yogyakarta: Amara Books.

Soejito, I. (1978). Tehnik membuat peraturan daerah. Yayasan Karya Dharma, Institut Ilmu Pemerintahan.

Soenobo, W. (2004). Proses \& Perencanaan Peraturan Perundang-Undangan. Jakarta: Ghalia Indonesia.

Sugiyono. (2012). Metode Penelitian Kuantitatif, Kualitatif dan R \& D.Bandung:Alfabeta. Metode Penelitian Kuantitatif, Kualitatif Dan R \& D.Bandung:Alfabeta. https://doi.org/10.1017/CBO9781107415324.004

Sukoco, N. P. (2012). Peran Badan Legislasi Dalam Pembentukan Peraturan Daerah Inisiatif Dewan Perwakilan Rakyat Daerah Provinsi Jawa Timur. Jejaring Administrasi Publik.

Suryono, H. (2005). Kenegaraan Perundang-Undangan: Perspektif Sosiologis Normatif dalam Teori dan Praktek. UNS Press, Surakarta.

Tafal, B. B. (1992). Pokok-Pokok tata hukum di Indonesia. Gramedia Pustaka Utama. 
Telaumbanua, D. (2019). Undang-Undang Republik Indonesia Nomor 15 Tahun 2019 tentang Perubahan Atas Undang-Undang Nomor 12 Tahun 2011 tentang Pembentukan Peraturan PerundangUndangan.

Uha, I. N. (2013). Budaya Organisasi Kepemimpinan dan Kinerja. Jakarta: Kencana.

Undang-Undang, R. I. (2015). Nomor 9 Tahun 2015. Perubahan Kedua Atas UU Nomor, 23.

Wiratsongko, S. (2017). Pengawasan DPRD Sleman Terhadap Pelaksanaan Peraturan Daerah Kabupaten Sleman Nomor 9 Tahun 2012 Tentang Retribusi Izin Trayek.

Yasin, S., \& Hapsoyo, S. (2008). Kamus Besar Bahasa Indonesia, Praktis, Populer dan Kosa Kata Baru. Surabaya: Mekar.

Yustisia, T. V. (2015). Undang-Undang No 23 Tahun 2014 tentang Pemerintahan Daerah dan Perubahannya. VisiMedia.

Yusuf, A. M. 2014. Metode Penelitian Kuantitatif, Kualitatif, dan Penelitian Gabungan. Jakarta: Prenada Media Grup. 